\title{
PENGARUH PEMBERIAN PUPUK KANDANG KOTORAN AYAM DAN PUPUK NPK MUTIARA YARAMILA TERHADAP PERTUMBUHAN BIBIT KELAPA SAWIT (Elaeis guineensis Jacg.) PADA PEMBIBITAN PRE NURSERY
}

\section{MOHAMMAD HERTOS}

Dosen Fakultas Pertanian dan Kehutanan Universitas Muhammdiyah Palangkaraya.

\begin{abstract}
ABSTRAK
Penelitian ini bertujuan: (1) untuk mengetahui interaksi pemberian Pupuk Kandang Kotoran Ayam dan Pupuk NPK Mutiara Yaramila terhadap pertumbuhan bibit kelapa sawit pada pembibitan pre nursery dan (2) untuk mengetahui pengaruh faktor tunggal pemberian Pupuk Kandang Kotoran Ayam dan Pupuk NPK Mutiara Yamila terhadap pertumbuhan bibit kelapa sawit pada pembibitan pre nursery.

Percobaan ini menggunakan Rancangan Acak Lengkap (RAL) faktorial dengan dua faktor dan tiga ulangan. Kedua faktor yang diteliti adalah : Faktor I : Pemberian Pupuk Kandang Kotoran Ayam (P) yang terdiri dari 4 taraf, yaitu : $\mathrm{P}_{0}=0$ ton/ha, $\mathrm{P}_{1}=20$ ton/ha, $\mathrm{P}_{2}=30$ ton/ha, dan $\mathrm{P}_{3}=40$ ton/ha. Faktor II : Pemberian Pupuk NPK Mutiara Yaramila $(Y)$ yang terdiri dari 4 taraf, yaitu : $Y_{0}=0 \mathrm{~kg} / \mathrm{ha}, \mathrm{Y}_{1}=200 \mathrm{~kg} / \mathrm{ha}, \mathrm{Y}_{2}$ $=300 \mathrm{~kg} / \mathrm{ha}$, dan $Y_{3}=400 \mathrm{~kg} / \mathrm{ha}$.

Hasil penelitian yang diperoleh menunjukkan bahwa interaksi pemberian Pupuk Kandang Kotoran Ayam dan Pupuk NPK Mutiara Yaramila berpengaruh sangat nyata terhadap parameter tinggi bibit, diameter batang, panjang akar primer dan berat segar bibit. Sedangkan untuk parameter jumlah daun, interaksi kedua perlakuan tersebut tidak berpengaruh nyata atau sangat nyata.

Hasil tertinggi untuk parameter tinggi bibit umur 4, 8 dan $12 \mathrm{MST}(17,9 \mathrm{~cm}, 34,4 \mathrm{~cm}$ dan $44,3 \mathrm{~cm})$, diameter batang umur 4, 8 dan $12 \mathrm{MST}(0,57 \mathrm{~cm}, 0,60 \mathrm{~cm}$ dan 0,92 cm), panjang akar primer $(25,3 \mathrm{~cm})$ dan berat segar bibit (16,87 gram) diperoleh pada perlakuan interaksi pemberian Pupuk Kandang Kotoran Ayam dengan dosis 40 ton/ha dan Pupuk NPK Mutiara Yaramila dengan dosis $400 \mathrm{~kg} / \mathrm{ha}\left(\mathrm{P}_{3} \mathrm{Y}_{3}\right)$.
\end{abstract}

Kata Kunci :

\section{PENDAHULUAN}

Kelapa sawit (Elaeis guineensis Jacg) merupakan salah satu tanaman penghasil minyak nabati yang sangat penting. Dimasa kini kelapa sawit tumbuh sebagai tanaman budidaya yang tersebar di berbagai negara beriklim tropis bahkan subtropis di Asia, Amerika Selatan dan Afrika (Setyamidjaja, 2006).

Bagi Indonesia tanaman kelapa sawit memiliki arti penting bagi pembangunan perkebunan nasional, selain mampu menciptakan kesempatan kerja yang mengarah pada kesejahteraan masyarakat, juga sebagai sumber perolehan devisa negara. Masa depan agrobisnis kelapa sawit menunjukkan peran yang sangat signifikan bagi ekonomi Indonesia.

Perkembangan luas dan produksi perkebunan kelapa sawit di Indonesia selama sepuluh tahun terakhir telah meningkat dari 1.592.000 hektar pada tahun 1997 menjadi 6.513.000 hektar pada tahun 2007 atau meningkat $75 \%$ pertahun. Produksi juga meningkat dari 5.448 .000 ton pada tahun 1997 menjadi 17.300 .000 ton pada tahun 2007, hal ini menjadikan Indonesia mampu melampaui produksi minyak sawit Malaysia (Sunarko, 2009).

Perkebunan kelapa sawit di Indonesia luasnya telah mencapai lebih dari lima juta hektar, sehingga merupakan komoditi perkebunan terluas di Indonesia maupun dunia. Namun sangat 
disayangkan produktivitasnya masih rendah dan penyebarannya di tanah air tidak merata. Lahan perkebunan paling luas berda di pulau Sumatera dan Kalimantan (Anonim, 2008a; Anonim, 2008b).

Salah satu aspek terpenting agar terciptanya produksi panen yang maksimal adalah tersedianya bahan tanam (bibit) yang berkualitas. Bibit kelapa sawit yang berkualitas umumnya dihasilkan dari varietas unggul dan proses pembibitan yang baik (Anonim, 2008b).

Pembibitan kelapa sawit merupakan titik awal yang paling menentukan masa depan pertumbuhan kelapa sawit di lapangan. Bibit yang unggul merupakan modal dasar untuk mencapai produktivitas yang tinggi. Standar bibit yang baik dapat dilihat dari diameter batang (tegak), tinggi bibit (jagur), jumlah daun (cukup) dan tidak terlihat terserang hama dan penyakit. Seleksi bibit harus dilakukan dengan ketat secara bertahap mulai dari penerimaan kecambah sampai seleksi yang terakhir pada saat pemindahan ke lapangan (transplanting), seleksi bibit ketat karena bibit yang standar akan menentukan masa depan hasil panen dan kualitas tanaman (Anonim, 2009b).

Proses pembibitan yang baik dapat dilakukan antara lain dengan menyediakan sejumlah unsur hara untuk memenuhi pertumbuhan bibit selama di pembibitan. Salah satu cara yang dapat dilakukan untuk terciptanya kondisi yang baik pada media pembibitan kelapa sawit pada pembibitan Pre Nursery adalah dengan pemberian pupuk kandang kotoran ayam dan pupuk NPK Mutiara Yaramila.

Pemberian pupuk kandang kotoran ayam berfungsi untuk menyuburkan tanah dan membuat strukturnya remah hingga tak mudah memadat, meningkatkan kemampuan mengikat air dan sebagai sumber hara Nitrogen, Fosfor dan Kalium (Sutejo, 2000).

Pupuk NPK Mutiara Yaramila dapat meningkatkan kandungan unsur hara makro di dalam tanah seperti unsur Nitrogen, Fosfor dan Kalium (Lingga dan Marsono, 2001).

Tujuan ini bertujuan untuk mengetahui interaksi pemberian pupuk kandang kotoran ayam dan pupuk NPK Mutiara Yaramila terhadap pertumbuhan bibit kelapa sawit pada pembibitan Pre Nursery dan untuk mengetahui pengaruh tunggal pemberian pupuk kandang kotoran ayam dan pupuk NPK Mutiara Yaramila terhadap pertumbuhan bibit kelapa sawit pada pembibitan Pre Nursery.

\section{METODELOGI PENELITIAN}

\section{Tempat dan Waktu}

Penelitian ini dilaksanakan selama 3 bulan, yaitu dari bulan April sampai bulan Juni 2013, bertempat di Jalan G. Obos Km 5 Kantor BPTP kota Palangka Raya.

\section{Bahan dan Alat}

Bahan-bahan yang digunakan pada penelitian ini adalah : bibit kelapa sawit dengan varietas Yangambi berasal dari PT. GSIP Indonesia, pupuk kandang kotoran ayam, pupuk NPK Mutiara Yaramila, tanah gambut dan polybag ukuran $1 \mathrm{~kg}$.

Alat-alat yang digunakan pada penelitian ini adalah : meteran, timbangan, pisau, kamera, cangkul, ember, gayung dan alat tulis.

\section{Metode Penelitian}

Penelitian ini merupakan percobaan faktorial dengan dua faktor yang disusun berdasarkan Rancangan Acak Lengkap (RAL) faktorial dengan tiga ulangan. 
Faktor I : Pemberian Pupuk Kandang Kotoran Ayam $(P)$ yang terdiri dari 4 taraf, yaitu :

$\mathrm{P}_{0}=0$ ton $/$ ha $(0 \mathrm{gram} /$ polybag $)$

$P_{1}=20$ ton/ha (50 gram/polybag)

$\mathrm{P}_{2}=30$ ton $/$ ha $(75 \mathrm{gram} /$ polybag $)$

$\mathrm{P}_{3}=40$ ton/ha (100 gram/polybag)

Faktor II : Pemberian Pupuk NPK Mutiara Yaramila $(\mathrm{Y})$ yang terdiri dari 4 taraf, yaitu :

$Y_{0}=0 \mathrm{~kg} / \mathrm{ha}(0 \mathrm{gram} /$ polybag $)$

$Y_{1}=200 \mathrm{~kg} / \mathrm{ha}(0,50 \mathrm{gram} /$ polybag $)$

$\mathrm{Y}_{2}=300 \mathrm{~kg} / \mathrm{ha}(0,75 \mathrm{gram} /$ polybag $)$

$\mathrm{Y}_{3}=400 \mathrm{~kg} / \mathrm{ha}$ (1,00 gram $/$ polybag $)$

Dari perlakuan tersebut di atas, setelah dikombinasikan diperoleh 16 kombinasi perlakuan seperti pada Tabel 1.

\section{Pelaksanaan Penelitian}

Tanah yang digunakan untuk media tanam adalah tanah gambut yang diambil di Kelurahan Kalampangan, Kecamatan Sabangau, Kota Palangka Raya. Tanah gambut diambil pada Ke dalaman $0-20 \mathrm{~cm}$. Kemudian dikeringanginkan selama satu minggu pada tempat terbuka. Setalah kering, tanah dihancurkan dan diayak dengan menggunakan ayakan tanah berukuran 25 mesh. Tanah ditimbang sebanyak $1 \mathrm{~kg}$, kemudian dicampur dengan pupuk kandang kotoran ayam sesuai dengan dosis perlakuan, kemudian masukan ke dalam polybag dan diinkubasi selama 2 minggu sebelum tanam.

Bibit kelapa sawit yang masih berbentuk kecambah ditanam pada polybag dengan cara membuat lubang pada media tanam sesuai dengan panjang akar yang telah berkembang. Setelah ditanam dilakukan penutupan dengan tanah kembali secukupnya.

Pupuk NPK Mutiara Yaramila sebagai perlakuan diberikan dua kali, yaitu pada saat tanam dan pada saat tanaman berumur 2 MST. Pupuk NPK Mutiara Yaramila diberikan dengan cara ditabur disekeliling tanaman dengan jarak 5 $\mathrm{cm}$ dari batang.

Pemeliharaan tanaman selama percobaan dilakukan secara intensif yang meliputi: penyulaman, penyiraman, penyiangan dan pengendalian hama dan penyakit.

Penyulaman dilakukan pada bibit kelapa sawit yang tumbuhnya tidak normal atau mati pada umur 2 MST.

Penyiraman dilakukan 2 kali sehari, yaitu : pagi dan sore hari dengan volume penyiraman yang sama pada masing-masing polybag. Penyiraman dilakukan dari saat tanam hingga akhir pengamatan.

Pengendalian gulma dilakukan dengan cara manual, yaitu dengan cara mencabut gulma yang tumbuh disekitar tanaman.

Pengendalian hama dan penyakit dilakukan dengan cara fisik, yaitu mematikan hama yang ada pada tanaman.

\section{Pengamatan}

Parameter yang diamati adalah :

1. Tinggi Bibit $(\mathrm{cm})$

Tinggi tanaman diukur dari pangkal batang hingga tajuk tanaman tertinggi. Pengamatan dilakukan pada saat tanaman berumur 4, 8 dan 12 MST.

2. Jumlah daun (helai)

Pengamatan jumlah daun dilakukan dengan cara menghitung jumlah helaian daun pada umur 4, 8 dan 12 MST.

3. Diamater Batang $(\mathrm{cm})$

Diameter batang diukur menggunakan jangka sorong pada tanaman $(5 \mathrm{~cm}$ diatas pangkal batang), diukur pada umur 4, 8 dan 12 MST. 
4. Berat Segar Bibit (gram)

Pengamatan berat segar bibit dilakukan setelah pembongkaran bibit, dengan cara menimbang bagian tajuk dan akar tanaman (dilakukan pada akhir pengamatan).

5. Panjang Akar Primer (cm)

Pengukuran panjang akar primer dilakukan dengan mencabut tanaman dan membersihkan dari tanah yang lengket pada akar dengan air bersih, kemudian diukur satu persatu (dilakukan pada akhir pengamatan).

\section{Analisis data}

Data dianalisis dengan menggunakan analisis ragam (uji $\mathrm{F}$ ) pada taraf $5 \%$ dan $1 \%$. Apabila uji $F$ menunjukkan adanya pengaruh perlakuan, maka dilanjutkan dengan uji beda ratarata menggunakan BNJ pada taraf $5 \%$.

\section{HASIL PENELITIAN DAN PEMBAHASAN}

\section{Hasil penelitian}

\section{Tinggi bibit}

Hasil analisis ragam menunjukkan bahwa interaksi perlakuan pemberian pupuk kandang kotoran ayam dan pupuk NPK Mutiara Yaramila berpengaruh sangat nyata terhadap tinggi bibit kepala sawit umur 4, 8 dan 12 MST. Hasil uji beda rata-rata untuk parameter tinggi bibit kelapa sawit disajikan pada Tabel 2.

Pada Tabel 2 terlihat bahwa rata-rata tinggi bibit kelapa sawit tertinggi pada umur 4, 8 dan 12 MST dihasilkan oleh perlakuan interaksi pemberian pupuk kandang kotoran ayam dengan dosis 40 ton/ha dan pupuk NPK Mutiara Yaramila dengan dosis $400 \mathrm{~kg} / \mathrm{ha}\left(\mathrm{P}_{3} \mathrm{Y}_{3}\right)$ dengan rata-rata setinggi $17,9 \mathrm{~cm}, 34,4 \mathrm{~cm}$ dan $44,3 \mathrm{~cm}$ dan berbeda nyata terhadap semua perlakuan lainnya, kecuali pada umur 12 MST dimana perlakuan
$\mathrm{P}_{3} \mathrm{Y}_{3}$ tidak berbeda nyata hanya dengan perlakuan $\mathrm{P}_{3} \mathrm{Y}_{2}$.

\section{Jumlah daun}

Hasil analisis ragam menunjukkan bahwa pemberian pupuk kandang kotoran ayam dan pupuk NPK Mutiara Yaramila secara tunggal maupun interaksinya tidak berpengaruh nyata atau sangat nyata terhadap parameter jumlah daun umur 4, 8 dan 12 MST.

\section{Diameter Batang}

Hasil analisis ragam menunjukkan bahwa interaksi perlakuan pemberian pupuk kandang kotoran ayam dan pupuk NPK Mutiara Yaramila berpengaruh sangat nyata terhadap parameter diameter batang umur 4, 8 dan 12 MST. Hasil uji beda rata-rata untuk parameter diameter batang disajikan pada Tabel 3.

Pada Tabel 3 terlihat bahwa rata-rata diameter batang terbesar umur 4,8 dan 12 MST dihasilkan oleh perlakuan interaksi pemberian pupuk kandang kotoran ayam dengan dosis 40 ton/ha dan pupuk NPK Mutiara Yaramila dengan dosis $400 \mathrm{~kg} / \mathrm{ha}\left(\mathrm{P}_{3} \mathrm{Y}_{3}\right)$ dengan rata-rata sebesar $0,57 \mathrm{~cm}, 0,60 \mathrm{~cm}$ dan $0,92 \mathrm{~cm}$ dan berbeda nyata terhadap semua perlakuan lainnya.

\section{Panjang Akar Primer dan Berat Segar Bibit}

Hasil analisis ragam menunjukkan bahwa interaksi perlakuan pemberian pupuk kandang kotoran ayam dan pupuk NPK Mutiara Yaramila berpengaruh sangat nyata terhadap parameter panjang akar primer dan berat segar bibit. Hasil uji beda rata-rata kedua parameter tersebut disajikan pada Tabel 4.

Pada Tabel 4 terlihat bahwa rata-rata panjang akar primer terpanjang dan berat segar bibit terbesar dihasilkan oleh perlakuan interaksi 
pemberian pupuk kandang kotoran ayam dengan dosis 40 ton/ha dan pupuk NPK Mutiara Yaramila dengan dosis $400 \mathrm{~kg} / \mathrm{ha}\left(\mathrm{P}_{3} \mathrm{Y}_{3}\right)$ dengan rata-rata $25,3 \mathrm{~cm}$ dan 16,87 gram dan berbeda nyata terhadap semua perlakuan lainnya.

\section{Pembahasan}

Perlakuan pupuk kandang kotoran ayam dan pupuk NPK Mutiara Yaramila secara bersama-sama berpengaruh sangat nyata terhadap tinggi bibit, diameter batang, panjang akar primer dan berat segar bibit. Untuk parameter jumlah daun pemberian pupuk kandang kotoran ayam maupun pupuk NPK Mutiara Yamila baik secara tunggal maupun interaksinya tidak berpengaruh pada parameter tersebut.

Pada pameter tinggi bibit, hasil tertinggi pada perlakuan pemberian pupuk kandang kotoran ayam dengan dosis 40 ton/ha dan pupuk NPK Mutiara Yaramila dengan dosis $400 \mathrm{~kg} / \mathrm{ha}$ $\left(\mathrm{P}_{3} \mathrm{Y}_{3}\right)$. Hal ini disebabkan karena pemberian pupuk tersebut dapat meningkatkan ketersediaan unsur N, P, K, Ca dan Mg (Lingga, 2000).

Peningkatan pertumbuhan vegetatif pada parameter tinggi bibit sangat dipengaruhi oleh adanya peranan unsur hara seperti $\mathrm{N}, \mathrm{P}$ dan $\mathrm{K}$. Lingga dan Marsono (2001) menjelaskan bahwa peranan nitrogen bagi tanaman adalah untuk merangsang pertumbuhan secara keseluruhan, khususnya cabang, batang dan daun. Nitrogen berfungsi sebagai pembentuk klorofil, protein dan lemak. Nitrogen juga sebagai penyusun enzim yang terdapat dalam sel, sehingga mempengaruhi pertumbuhan karbohidrat yang sangat berperan dalam pertumbuhan tanaman (Lingga, 2004). Sosrosoedirdjo (2004) menambahkan bahwa karbohidrat merupakan bahan yang sangat diperlukan dalam pembelahan sel, perpanjangan sel, pembesaran sel dan pembentukkan jaringan untuk perkembangan batang, daun dan akar. Fosfor berfungsi mengatasi pengaruh negatif dari nitrogen, memperbaiki perkembangan akar dan memperbaiki kualitas hasil. Kemudian $\mathrm{K}$ berfungsi dalam mengatur keseimbangan pupuk nitrogen dan fosfor (Jumin, 2000).

Untuk parameter jumlah daun, pemberian pupuk kandang kotoran ayam dan pupuk NPK Mutiara Yaramila secara tunggal maupun bersama-sama tidak menunjukkan adanya pengaruh nyata atau sangat nyata pada setiap umur pengamatannya. Hal ini diduga karena tanaman kelapa sawit merupakan tanaman tahunan sehingga pertumbuhan bibit khususnya perkembangan daun pada pembibitan pre nursery masih pada taraf pertumbuhan lambat, sehingga interaksi kedua perlakuan yang diberikan tidak terjadi.

Gardner, Pearce dan Mitchell (1991), mengemukakan bahwa pertumbuhan tanaman terdiri dari tiga fase pertumbuhan, yaitu fase logaritmik (fase lambat), fase linear (fase konstan) dan fase asimptotik (fase kelayuan). Pada fase logaritmik pertumbuhan tanaman berlangsung lambat pada awalnya tetapi kemudian berlangsung semakin cepat. Fase ini umumnya berlangsung pada 1-3 minggu pada tanaman semusim dan 1-3 bulan pada tanaman tahunan. Fase linear yaitu fase pertumbuhan tanaman berjalan konstan, fase asimptotik dicirikan dengan laju pertumbuhan tanaman semakin menurun.

Untuk parameter diameter batang, sama halnya dengan parameter tinggi bibit, dimana rata-rata diameter batang terbesar pada setiap umur pengamatannya dihasilkan oleh perlakuan 
pemberian pupuk kandang kotoran ayam sebesar 40 ton/ha dan pupuk NPK Mutiara Yaramila sebesar $400 \mathrm{~kg} / \mathrm{ha}\left(\mathrm{P}_{3} \mathrm{Y}_{3}\right)$. Hal ini disebabkan karena kedua unsur tersebut secara bersamasama mampu memberikan pertumbuhan tanaman yang baik. Pertumbuhan yang baik diindikasikan dengan kemampuan tanaman untuk berfotosintesis lebih tinggi dan hasil fotosintesis (fotosintat) yang dihasilkan lebih banyak. Fotosintat yang lebih banyak ditranslokasi lewat floem dan dapat digunakan untuk memacu pertumbuhan sekunder yaitu perluasan sel batang dan diindikasikan dengan diameter batang yang lebih lebar. Menurut Gardner dkk (1991), pertumbuhan dan perkembangan tanaman dan organ-organnya akan bergantung oleh tersedianya meristem, hormon dan hasil fotosintesis (karbohidrat) serta lingkungan yang mendukung. Meristem lateral menghasilkan selsel baru yang memperluas lebar atau diameter suatu organ. Kambium vaskuler merupakan suatu meristem lateral yang terspesialisasi yang membentuk xilem dan floem sekunder. Loveless (1987), menambahkan bahwa pertambahan diameter batang terkait oleh adanya pertumbuhan sekunder termasuk pembelahan sel-sel di daerah kambium dan pembentukkan jaringan xilem dan floem.

Pada parameter panjang akar primer dimana panjang akar terpanjang, yaitu sebesar
25,3 cm dihasilkan oleh perlakuan pemberian pupuk kandang kotoran ayam dengan dosis 40 ton/ha dan pupuk NPK Mutiara Yaramila dengan dosis $400 \mathrm{~kg} / \mathrm{ha}\left(\mathrm{P}_{3} \mathrm{Y}_{3}\right)$ hal ini disebabkan karena kedua perlakuan yang diberikan pada tanah gambut mampu memperbaiki sifat kimia tanah tersebut yang pada akhirnya akan meningkatkan $\mathrm{pH}$ tanah, sehingga unsur hara makro yang diperlukan oleh tanaman, baik yang ada di dalam tanah maupun lewat pemberian kedua pupuk tersebut khususnya unsur $\mathrm{P}$ tersedia dan dapat diserap oleh tanaman. Peranan $\mathrm{P}$ pada pertumbuhan vegetatif tanaman adalah untuk memacu pertumbuhan akar dan pembentukkan sistem perakaran, juga sebagai bahan penyusun inti sel, lemak dan protein (Dwidjosepurto, 2000).

Adanya pengaruh positif terhadap peningkatan berat segar bibit, hal ini disebabkan karena adanya peningkatan terhadap tinggi tanaman, jumlah daun, diameter batang dan panjang akar primer. Lingga (2004) menyatakan bahwa pertumbuhan tanaman tergantung pada imbangan fotosintesis yang mengimbangi karbohidrat dan bahan tanam serta respirasi. Fotosintesis pada umumnya terjadi pada hijau daun yang berklorofil, maka sampai fase tertentu laju fotosintesis akan meningkat dengan meningkatnya jumlah daun serta pertumbuhan tanaman akan mengikutinya.

Tabel 1. Kombinasi Perlakuan

\begin{tabular}{|c|c|c|c|c|}
\hline \multirow{2}{*}{$\begin{array}{c}\text { Pupuk Kandang } \\
(P)\end{array}$} & \multicolumn{4}{|c|}{ Pupuk NPK Mutiara Yaramila (Y) } \\
\cline { 2 - 5 } & $\mathrm{Y}_{0}$ & $\mathrm{Y}_{1}$ & $\mathrm{Y}_{2}$ & $\mathrm{Y}_{3}$ \\
\hline $\mathrm{P}_{0}$ & $\mathrm{P}_{0} \mathrm{Y}_{0}$ & $\mathrm{P}_{0} \mathrm{Y}_{1}$ & $\mathrm{P}_{0} \mathrm{Y}_{2}$ & $\mathrm{P}_{0} \mathrm{Y}_{3}$ \\
$\mathrm{P}_{1}$ & $\mathrm{P}_{1} \mathrm{Y}_{0}$ & $\mathrm{P}_{1} \mathrm{Y}_{1}$ & $\mathrm{P}_{1} \mathrm{Y}_{2}$ & $\mathrm{P}_{1} \mathrm{Y}_{3}$ \\
$\mathrm{P}_{2}$ & $\mathrm{P}_{2} \mathrm{Y}_{0}$ & $\mathrm{P}_{2} \mathrm{Y}_{1}$ & $\mathrm{P}_{2} \mathrm{Y}_{2}$ & $\mathrm{P}_{2} \mathrm{Y}_{3}$ \\
$\mathrm{P}_{3}$ & $\mathrm{P}_{3} \mathrm{Y}_{0}$ & $\mathrm{P}_{3} \mathrm{Y}_{1}$ & $\mathrm{P}_{3} \mathrm{Y}_{2}$ & $\mathrm{P}_{3} \mathrm{Y}_{3}$ \\
\hline
\end{tabular}


Tabel 2. Hasil uji beda rata-rata tinggi bibit kelapa sawit umur 4, 8, dan 12 MST.

\begin{tabular}{|c|c|c|c|}
\hline \multirow{2}{*}{ Perlakuan } & \multicolumn{3}{|c|}{ Tinggi Bibit } \\
\cline { 2 - 4 } & $\mathbf{4} \mathbf{M S T}$ & $\mathbf{8} \mathbf{M S T}$ & $\mathbf{1 2} \mathbf{M S T}$ \\
\hline & $5,0 \mathrm{a}$ & $15,7 \mathrm{a}$ & $20,3 \mathrm{a}$ \\
$\mathrm{P}_{0} \mathrm{Y}_{0}$ & $5,7 \mathrm{a}$ & $17,0 \mathrm{ab}$ & $21,0 \mathrm{a}$ \\
$\mathrm{P}_{0} \mathrm{Y}_{1}$ & $8,2 \mathrm{~b}$ & $17,7 \mathrm{ab}$ & $21,3 \mathrm{a}$ \\
$\mathrm{P}_{0} \mathrm{Y}_{2}$ & $8,2 \mathrm{~b}$ & $17,8 \mathrm{ab}$ & $21,7 \mathrm{a}$ \\
$\mathrm{P}_{0} \mathrm{Y}_{3}$ & $8,3 \mathrm{~b}$ & $18,6 \mathrm{abc}$ & $26,0 \mathrm{~b}$ \\
$\mathrm{P}_{1} \mathrm{Y}_{0}$ & $8,4 \mathrm{~b}$ & $19,2 \mathrm{bc}$ & $26,0 \mathrm{~b}$ \\
$\mathrm{P}_{1} \mathrm{Y}_{1}$ & $8,8 \mathrm{~b}$ & $21,2 \mathrm{~cd}$ & $27,7 \mathrm{bc}$ \\
$\mathrm{P}_{1} \mathrm{Y}_{2}$ & $9,3 \mathrm{bc}$ & $22,4 \mathrm{de}$ & $28,0 \mathrm{bc}$ \\
$\mathrm{P}_{1} \mathrm{Y}_{3}$ & $9,8 \mathrm{bcd}$ & $23,1 \mathrm{def}$ & $28,7 \mathrm{bc}$ \\
$\mathrm{P}_{2} \mathrm{Y}_{0}$ & $9,9 \mathrm{bcd}$ & $25,3 \mathrm{efg}$ & $29,0 \mathrm{bc}$ \\
$\mathrm{P}_{2} \mathrm{Y}_{1}$ & $10,3 \mathrm{bcde}$ & $26,0 \mathrm{fg}$ & $30,3 \mathrm{c}$ \\
$\mathrm{P}_{2} \mathrm{Y}_{2}$ & $11,3 \mathrm{cde}$ & $26,7 \mathrm{~g}$ & $31,0 \mathrm{c}$ \\
$\mathrm{P}_{2} \mathrm{Y}_{3}$ & $12,0 \mathrm{de}$ & $27,3 \mathrm{~g}$ & $36,0 \mathrm{~d}$ \\
$\mathrm{P}_{3} \mathrm{Y}_{0}$ & $12,3 \mathrm{e}$ & $27,3 \mathrm{~g}$ & $36,3 \mathrm{~d}$ \\
$\mathrm{P}_{3} \mathrm{Y}_{1}$ & $14,1 \mathrm{f}$ & $28,2 \mathrm{~g}$ & $43,7 \mathrm{e}$ \\
$\mathrm{P}_{3} \mathrm{Y}_{2}$ & $17,9 \mathrm{~g}$ & $34,4 \mathrm{~h}$ & $44,3 \mathrm{e}$ \\
$\mathrm{P}_{3} \mathrm{Y}_{3}$ & & & \\
\hline BNJ $5 \%$ & 2,93 & 3,10 & 3,90 \\
\hline
\end{tabular}

Keterangan : Angka-angka yang didampingi huruf yang sama pada kolom yang sama tidak berbeda nyata pada uji BNJ taraf $5 \%$.

Tabel 3. Hasil uji beda rata-rata Diameter Batang umur 4, 8, dan 12 MST.

\begin{tabular}{|l|c|c|c|}
\hline \multirow{2}{*}{ Perlakuan } & \multicolumn{3}{|c|}{ Tinggi Bibit } \\
\cline { 2 - 4 } & $\mathbf{4 ~ M S T}$ & $\mathbf{8 ~ M S T}$ & $\mathbf{1 2} \mathbf{~ M S T}$ \\
\hline $\mathrm{P}_{0} \mathrm{Y}_{0}$ & $0,15 \mathrm{a}$ & $0,20 \mathrm{a}$ & $0,22 \mathrm{a}$ \\
$\mathrm{P}_{0} \mathrm{Y}_{1}$ & $0,19 \mathrm{~b}$ & $0,20 \mathrm{a}$ & $0,24 \mathrm{a}$ \\
$\mathrm{P}_{0} \mathrm{Y}_{2}$ & $0,20 \mathrm{~b}$ & $0,21 \mathrm{a}$ & $0,28 \mathrm{ab}$ \\
$\mathrm{P}_{0} \mathrm{Y}_{3}$ & $0,21 \mathrm{~b}$ & $0,21 \mathrm{a}$ & $0,33 \mathrm{bc}$ \\
$\mathrm{P}_{1} \mathrm{Y}_{0}$ & $0,20 \mathrm{~b}$ & $0,23 \mathrm{a}$ & $0,35 \mathrm{c}$ \\
$\mathrm{P}_{1} \mathrm{Y}_{1}$ & $0,22 \mathrm{~b}$ & $0,25 \mathrm{ab}$ & $0,39 \mathrm{~cd}$ \\
$\mathrm{P}_{1} \mathrm{Y}_{2}$ & $0,22 \mathrm{~b}$ & $0,30 \mathrm{bc}$ & $0,43 \mathrm{de}$ \\
$\mathrm{P}_{1} \mathrm{Y}_{3}$ & $0,22 \mathrm{~b}$ & $0,31 \mathrm{c}$ & $0,43 \mathrm{de}$ \\
$\mathrm{P}_{2} \mathrm{Y}_{0}$ & $0,21 \mathrm{~b}$ & $0,33 \mathrm{c}$ & $0,46 \mathrm{ef}$ \\
$\mathrm{P}_{2} \mathrm{Y}_{1}$ & $0,26 \mathrm{c}$ & $0,35 \mathrm{~cd}$ & $0,50 \mathrm{fg}$ \\
$\mathrm{P}_{2} \mathrm{Y}_{2}$ & $0,30 \mathrm{~d}$ & $0,40 \mathrm{de}$ & $0,52 \mathrm{fg}$ \\
$\mathrm{P}_{2} \mathrm{Y}_{3}$ & $0,33 \mathrm{de}$ & $0,42 \mathrm{e}$ & $0,56 \mathrm{gh}$ \\
$\mathrm{P}_{3} \mathrm{Y}_{0}$ & $0,36 \mathrm{e}$ & $0,43 \mathrm{e}$ & $0,60 \mathrm{~h}$ \\
$\mathrm{P}_{3} \mathrm{Y}_{1}$ & $0,43 \mathrm{f}$ & $0,45 \mathrm{e}$ & $0,70 \mathrm{i}$ \\
$\mathrm{P}_{3} \mathrm{Y}_{2}$ & $0,51 \mathrm{~g}$ & $0,53 \mathrm{f}$ & $0,81 \mathrm{j}$ \\
$\mathrm{P}_{3} \mathrm{Y}_{3}$ & $0,57 \mathrm{~h}$ & $0,60 \mathrm{~g}$ & $0,92 \mathrm{k}$ \\
\hline BNJ 5\% & 0,03 & 0,05 & 0,06 \\
\hline Bngka & & & \\
\hline
\end{tabular}

Keterangan : Angka-angka yang didampingi huruf yang sama pada kolom yang sama tidak berbeda nyata pada uji BNJ taraf $5 \%$. 
Tabel 4. Hasil uji beda rata-rata panjang akar primer (cm) dan berat segar bibit (gram).

\begin{tabular}{|c|c|c|}
\hline Perlakuan & Panjang Akar Primer & Berat Segar Bibit \\
\hline & $8,4 \mathrm{a}$ & $1,32 \mathrm{a}$ \\
$\mathrm{P}_{0} \mathrm{Y}_{0}$ & $9,0 \mathrm{ab}$ & $1,48 \mathrm{ab}$ \\
$\mathrm{P}_{0} \mathrm{Y}_{1}$ & $9,3 \mathrm{bc}$ & $2,54 \mathrm{bc}$ \\
$\mathrm{P}_{0} \mathrm{Y}_{2}$ & $9,9 \mathrm{bcd}$ & $2,66 \mathrm{c}$ \\
$\mathrm{P}_{0} \mathrm{Y}_{3}$ & $10,1 \mathrm{~cd}$ & $3,17 \mathrm{c}$ \\
$\mathrm{P}_{1} \mathrm{Y}_{0}$ & $10,8 \mathrm{~d}$ & $4,13 \mathrm{~d}$ \\
$\mathrm{P}_{1} \mathrm{Y}_{1}$ & $12,0 \mathrm{e}$ & $4,64 \mathrm{de}$ \\
$\mathrm{P}_{1} \mathrm{Y}_{2}$ & $13,8 \mathrm{f}$ & $5,17 \mathrm{de}$ \\
$\mathrm{P}_{1} \mathrm{Y}_{3}$ & $15,6 \mathrm{~d}$ & $5,30 \mathrm{ef}$ \\
$\mathrm{P}_{2} \mathrm{Y}_{0}$ & $15,7 \mathrm{~g}$ & $6,39 \mathrm{fg}$ \\
$\mathrm{P}_{2} \mathrm{Y}_{1}$ & $17,0 \mathrm{~h}$ & $7,37 \mathrm{gh}$ \\
$\mathrm{P}_{2} \mathrm{Y}_{2}$ & $18,0 \mathrm{i}$ & $8,17 \mathrm{hi}$ \\
$\mathrm{P}_{2} \mathrm{Y}_{3}$ & $21,2 \mathrm{j}$ & $8,60 \mathrm{i}$ \\
$\mathrm{P}_{3} \mathrm{Y}_{0}$ & $21,7 \mathrm{j}$ & $10,54 \mathrm{j}$ \\
$\mathrm{P}_{3} \mathrm{Y}_{1}$ & $22,0 \mathrm{j}$ & $13,13 \mathrm{k}$ \\
$\mathrm{P}_{3} \mathrm{Y}_{2}$ & $25,3 \mathrm{k}$ & $16,87 \mathrm{I}$ \\
$\mathrm{P}_{3} \mathrm{Y}_{3}$ & & \\
\hline BNJ $5 \%$ & 0,91 & 1,10 \\
\hline Ang & & $\mathrm{gang}$ \\
\hline
\end{tabular}

Keterangan : Angka-angka yang didampingi huruf yang sama pada kolom yang sama tidak berbeda nyata pada uji BNJ taraf $5 \%$.

\section{KESIMPULAN DAN SARAN}

\section{Kesimpulan}

Interaksi pemberian Pupuk Kandang Kotoran Ayam dan Pupuk NPK Mutiara Yaramila berpengaruh sangat nyata terhadap parameter tinggi bibit, diameter batang, panjang akar primer dan berat segar bibit. Sedangkan untuk parameter jumlah daun, interaksi kedua perlakuan tersebut tidak berpengaruh nyata atau sangat nyata.

Hasil tertinggi untuk parameter tinggi bibit umur 4,8 dan 12 MST $(17,9 \mathrm{~cm}, 34,4 \mathrm{~cm}$, dan $44,3 \mathrm{~cm}$ ), diameter batang umur 4,8 dan $12 \mathrm{MST}$ $(0,57 \mathrm{~cm}, 0,60 \mathrm{~cm}$, dan $0,92 \mathrm{~cm})$, panjang akar primer $(25,3 \mathrm{~cm})$ dan berat segar bibit $(16,87$ gram) diperoleh pada perlakuan interaksi pemberian Pupuk Kandang Kotoran Ayam dengan dosis 40 ton/ha dan Pupuk NPK Mutiara Yaramila dengan dosis $400 \mathrm{~kg} / \mathrm{ha}\left(\mathrm{P}_{3} \mathrm{Y}_{3}\right)$.

\section{Saran}

Dalam melakukan pembibitan kelapa sawit pada tahapan pre nursery di tanah gambut disarankan untuk mempertimbangkan pemakaian Pupuk Kandang Kotoran Ayam sebesar 40 ton/ha dengan Pupuk NPK Mutiara Yaramila sebesar $400 \mathrm{~kg} / \mathrm{ha}$.

\section{DAFTAR PUSTAKA}

Anonim. 2008a. Pedoman Teknis Pembibitan Kelapa Sawit (Pre Nursery). PT.Socfin Indonesia. Medan.

Anonim. 2008b. Kiat Sukses Pembibitan Kelapa Sawit. www.google.com Tanggal Akses 27 Maret 2012. 
Anonim. 2009a. Pemerintah Akan Membangun Lembaga Riset Kelapa Sawit Berskala Besar. $\quad$ http://ditjenbun.deptan.go.id. Tanggal Akses 27 Maret 2012.

Anonim. 2009b. Pembibitan Kelapa Sawit. www.google.com Tanggal Akses 28 Maret 2012.

Anonim. 2011. Brosur Pupuk NPK Mutiara Yaramila. PT. Maraoke Tetap Jaya Indonesia. Palangka Raya.

Dwidjoseputro. 2000. Pengantar Fisiologi

Tumbuhan. PT. Gramedia. Jakarta.

Gardner, F.P., R.B. Pearce dan R.I. Mitchell. 1991. Fisiologi Tanaman Budidaya, UI Press Jakarta.

Jumin. 2000. Dasar-dasar Agronomi. Rajawali. Bandung.

Loveless, A.R. 1987. Prinsip-prinsip Biologi Tumbuhan untuk Daerah Tropik. Jilid I. Gramedia. Jakarta.

Lingga. 2004. Petunjuk Penggunaan Pupuk. Penenbar Swadaya. Jakarta.

Soepardi, G. 1988. Sifat dan Ciri Tanah.

Departeman IImu Tanah IPB. Bogor.

Sutejo, M.M. 2000. Pupuk dan Cara Pemupukan. Penerbit Rineka Cipta. Jakarta.

Sosrosoedirdjo. 2004. IImu Memupuk. Jilid I. CV. Yasaguna. Jakarta. 